\title{
Food Sustainability: Visually Speaking
}

Writer: Melissa Cloutier*

Photographers: Lindsay Drennan, Breanne Kshyk, Wendy Mulder, Amanda Swanson, Loren Webb*

Grant MacEwan University, Canada

\begin{abstract}
Food sustainability at Edmonton's regional, city, community and personal level is visually presented within a VCPH 340 Documentary Photography final project. This article reveals how the final project inspired a group of design students to cultivate the concept of, raise awareness about and promote food sustainability activism within and around Edmonton, Alberta, Canada.
\end{abstract}

\section{The Project}

In the Design Studies Program VCPH 340 Documentary Photography winter course (2012), instructor James Parker introduced a final group project that gave teams a number of thematic topics to select from - including water conservation, recycling, and food sustainability - to produce a set of documentary photos for presenting in the last week of the term. Amanda Swanson, Breanne Kshyk, Loren Webb, Lindsay Drennan, and Wendy Mulder chose food sustainability as the topic for their project. They developed the project throughout the term while multi-tasking other assignments. The purpose for such a project is described by Inwood (2010):

... by better connecting art to the realities of daily living, art can be used effectively as an agent of social change, one that would capture the 
public's attention through its creative, innovative approaches to

society's problems. By documenting a growing trend in artmaking that related artmaking to environmental concerns, Gablik provided art educators with an entrée to art focused on the environment, as well as an aesthetic framework...(Inwood, 2010, p. 34)

Hence, documentary photography was used as a means for delving into local environmental issues on various levels to promote social activism in food sustainability and an environmentally friendly means of living in our society.

\section{The Composition}

The project required the design students to use standard equipment and software such as their cameras (Nikon D90), tripods, computer, and Photoshop to name a few. This team took the project a step further though by using video with iMovie for the project and showcasing interviews about their topic within the video. Furthermore, the video was tactfully arranged based on content. For instance, certain video clips focused on what interviewees had to say whereas imagery, sound and energy were the priorities in other footage.

Having multiple layers of perspectives and representation adds more depth and credibility to a documentary project and also speaks to a more vast audience. The food sustainability project was divided into, researched, photographed and recorded in sections: considering regional, city, community and personal perspectives provided the project with a wholesome outlook, which is a requirement of documentary photography according to Jing \& Yun (2007):

One significant feature of documentary photography is its relationship to time and subject matter. Unlike news pictures that stress eventfulness, movement and shock effect, a documentary project takes much longer for the author to study, as well as experience and understanding of the interrelations of social conditions, cultural values, and people's life. In the process, the author develops a close connection with subjects, while trying to convey, through a series of visual narratives, a particular way of understanding social life in time and space. Often a documentary photographer is not merely a traditional artist seeking the means of personal expression, but a social reformer hoping to use visual means for 
social research, to communicate social awareness of previously ignored social facts... (Jing \& Yun, 2007, p. 42).

Loren emphasized that achieving documentary photography also requires following a strict code of ethics: "The Code of Ethics for documentary photography helps to guide the imagery towards honesty - any images captured are held strictly to the integrity of that true moment, not to the intentions of the photographer or the subject," (Webb, interview, June 3, 2010).

Members photographed their individual sections. Wendy and Loren completed the regional section together (each chose five photos) while the other group members managed their own assigned sections in which they developed 10 photos each. Wendy was responsible for the video footage, which acted as a bridge between perspectives and sections that anchored the project and helped connect themes. Loren found the quote and facts for the regional section from Alberta Rural Sustainable Alternatives Network (ARSAN), and the remaining members discovered their own facts and quotes within their course journals or via blog researching and interviewing.

To select photos, group members individually chose the ones they felt were strongest, printed their chosen photos in black and white, met at the school to sift through every section's photos and voted for the ones they felt weaved a story. The project avoided repetition and overlap through this process of elimination. The intentional placement of potato photos in every section and distributing potato giveaways also helped weave a theme throughout the project.

While presenting the video, the group thoughtfully gave classmates a potato, from one of the visited farms, packaged with a potato recipe card to help promote their topic. Group members searched sustainable food recipes and also wrote where to locally find the ingredients.

The project grew by completing a series of steps. Firstly, the group members learnt the meaning of food sustainability to explore the term visually. Secondly, individuals decided what they would photograph and how to visually represent personal, community, city and regional perspectives of food sustainability to show that it is being achieved. Thirdly, the students researched their assigned sections to discuss the topic with experts; then the members conducted their interviews and captured photographs that represented the sections they were assigned. Following this, individuals edited and organized the information and photography that they had gathered. Finally members grouped together at school over approximately a five-hour period and later at Wendy's house to assemble their video and photography into a short documentary movie through 
a voting elimination process that considered relativity, along with compiling giveaways for classmates. These giveaways consisted of potatoes wrapped in scrap fabric that was tied with yarn with recipe cards attached.

\section{Inspirational Research}

Blogs were a main source of research and information. A blog that was closely followed was of interviewee, Kevin Kossowan, whose blog has approximately 40 videos. Kevin represented the city section of the project and enforces the ability of an Edmontonian to become part of the local food sustainability movement by sharing with the public his participation and activism in food sustainability. The group felt he epitomized this section because he is actively involved in learning, videoing and informing about food sustainability within Edmonton and teaching the public how food sustainability is achieved with relative ease. Lindsay described Kevin's personal achievements that show how food sustainability is beneficial in various ways: "His seed budget for the year was a $\$ 100$ and that feeds his family of four all the veggies they eat for the entire year," (Interview, May 25, 2012).

For the regional section, Wendy had personal connections with some regional farms and so she interviewed farmers, including her boyfriend who is a dairy farmer, and Loren researched the ARSAN's website to develop content for their section. Interviewing the storeowner of Wild Earth Foods, which is near Lindsay's house, via email helped Lindsay to develop content for the community section of the project. This food store supplies sustainable products and stocks a lot of local items. Lindsay also had personal connections to the store because the location is near her residence and she shops there. The personal section's content derived from Breanne's research of an online company that ships local organic food to consumers' doorsteps. She and Wendy also went to the Strathcona farmer's market to experience and research a local sustainable food environment. They learned that market offers more variety than just vegetables such as bagels, salsa, dried mushrooms, lotions and more.

"At the beginning, at least for me, even Loren, I think, we were like what is this topic? It's so broad. What are we researching?... I think we had to know... what's Edmonton's role in food sustainability?" (Wendy, interview, May 25, 2012). Learning this required delving into the food scene; understanding terms was crucial. Grace (2007) describes sustainability as: 
the ability to provide for the needs of the world's current population without damaging the ability of future generations to provide for themselves. When a process is sustainable, it can be carried out over and over without negative environmental effects or impossibly high costs to anyone involved.”

As well the project required group members to research within the Edmonton area and consider food miles for the project to meet food sustainability standards. The following is Gold's (2007) definition of food miles: “...the distance food travels from where it is grown or raised to where it is ultimately purchased by the consumer or enduser," (Gold, 2007). Therefore, the scope of the project and of the interviewees must have abided by this defined range, and by the definition of sustainability.

\section{Documentary Photography and Food Sustainability}

Inwood (2010) suggests environmental art that is educational should achieve a sense of the following: "Whether grounded on scientific or aesthetic footings, they recommend a pedagogy that is community-based, interdisciplinary, experiential, interactive, dialogic, ideologically aware, and built on the values of empathy, sustainability, and respect for the environment," (Inwood, 2010, 34). This documentary movie practices all of the previously mentioned elements of environmental art that is educational. The movie also visually speaks to how achievable and beneficial food sustainability is within our present society, which is a social awareness tool of documentary photography that is used to voice the need for change. Breanne described her experience with the project: "Working on a long term documentary photography project was interesting because it really allows you to dig into the subject and see it from multiple points of view. Through this I learned more about food sustainability then I ever thought I would!"

Food sustainability provides a solution for how we eat and how and what we eat is impacting society on a global level: "Issues of personal health and global hunger, the instability of oil-dependent economies, growing agricultural trade surpluses, genetic engineering, the loss of regional crop varieties, the ethical treatment of animals, and the impact of farms on our environment are all part of a daily dynamic we participate in every time we eat, "(Houston, 2007, 2). Social awareness of these issues can be raised via documentary photography. 
Amanda explained that the movie delivers a message: "Lots of people were like well they say its too hard to do sustainability, or I'm in the city - it's impossible, or it's too expensive and we punched holes in every single one of those... Anyone can do it, you just have to be willing to put the effort into it," (interview, May 25, 2012). This documentary photographic movie speaks to and inspires others to become more food sustainable.

*Writer: Melissa Cloutier is a fourth year student in the Bachelor of Applied Communications in Professional Writing program. She has a passion for writing, photography, and the environment.

Photographers: Lindsay Drennan, Breanne Kshyke, Wendy Mulder,

Amanda Swanson, Loren Webb_ are Design Studies students who worked collaboratively to develop the ethnophotography segment of this article.

\section{References}

Grace. (2007). In Sustainable Dictionary. Sustainable Table. Retrieved from http://www.sustainabletable.org/intro/dictionary/

Gold. (2007). Sustainable Agriculture: Definitions and Terms. In Alternative Farming Systems Information Center's Publications. United States Department of Agriculture.

Retrieved July 31, 2012 from

http://www.nal.usda.gov/afsic/pubs/terms/srb9902terms.shtml.

Houston, J. (2007). The American Farm. Gastronomica, 7(3), 24-27.

Inwood, H. (2010). Shades of Green: Growing Environmentalism through Art Education. Art Education, 63(6), 33-38.

Jing, W., \& Yun, G. (2007). Beyond Propaganda, Aestheticism and Commercialism: The Coming of Age of Documentary Photography in China. Javnost-The Public, 14(3), 3148. 